\title{
SEEDS ECOPHYSIOLOGY IN AN ALTITUDE MARSH IN PARAÍBA STATE, BRAZIL, AIMING THE CONSERVATION OF THE AUTOCHTHONOUS BIODIVERSITY
}

\author{
ECOFISIOLOGIA DE SEMENTES EM BREJO DE ALTITUDE NA PARAÍBA VISANDO À \\ CONSERVAÇÃO DA BIODIVERSIDADE AUTÓCTONE
}

\author{
Robson Luis Silva de Medeiros ${ }^{1}$ Vênia Camelo de Souza ${ }^{2}$ José Nailson Barros Santos ${ }^{3}$ \\ Gilvaneide Alves de Azeredo ${ }^{4}$ Fabiana dos Anjos ${ }^{5}$
}

\begin{abstract}
The altitude swamps in northeast Brazil are areas with divergent microclimates from the context that theyare located, their forest formations are disjunctions of the Atlantic Forest, marooned by the 'Caatinga' vegetation, a condition that makes these remaining areas with high biodiversity. Botanical research in remnants forests of Paraíba state, particularly with regard to the redemption of germplasm, are relevant. The aim of this study was to evaluate the ecophysiology of seeds from native species of the Fabaceae family selected in the CCHSA forest fragment, submitted to thermal stress and monitor their reproductive phenophases. The experiment was conducted at the Seed Laboratory of the CCHSA/UFPB and with the aid of B.O.D germinators, with 8 hours of photoperiod in a randomized experiment design with constant temperatures of $20,25,30$ and $40^{\circ} \mathrm{C}$. The seeds were distributed on a paper towel moistened with distilled water equivalent to three times the weight of the dry paper. Four replicates of 25 seeds were used per treatment. Data of germination and Germination Speed Index (GSI) were submitted to analysis of variance and polynomial regression. The germination of Pterogyne nitens Tul. was affected by the studied temperatures and the temperature range that promoted higher germination percentage between 25 and $40^{\circ} \mathrm{C}$. The higher temperature $\left(40^{\circ} \mathrm{C}\right)$ markedly increased the germination and vigor of Senegalia tenuifolia L. Britton and Rose. The higher GSI was observed for Enterolobium contortisiliquum (Vell.) with the use of $40^{\circ} \mathrm{C}$ of temperature. The results can indicate the optimum temperature and range temperature for germination and early seedling development of the species studied in its habitat.
\end{abstract}

Keywords: native forest seed; Atlantic Forest; abiotic factors.

\section{RESUMO}

Os brejos de altitude nordestinos são áreas que apresentam microclimas dissociantes do contexto onde estão inseridos, suas formações florestais são disjunções de floresta atlântica, ilhadas pela vegetação da Caatinga, condição que torna essas áreas remanescentes de elevada biodiversidade. Pesquisas botânicas nos remanescentes florestais da Paraíba, particularmente no que se refere ao resgate de germoplasma são relevantes. Objetivou-se estudar a ecofisiologia das sementes de espécies (Anadenanthera colubrina, Pterogyne nitens, Enterolobium contortisiliquum e Senegalia tenuifolia) nativas da família Fabaceae

1 Licenciado em Ciências Agrárias, Mestrando em Agronomia (Produção Vegetal), Faculdade de Ciências Agrárias e Veterinárias, Universidade Estadual Paulista, Via de Acesso Prof. Paulo Donato 37 Castellane, s/n, CEP 14.884-900, Jaboticabal (SP), Brasil. robsonluissm@hotmail.com

2 Bióloga, Dr ${ }^{\mathrm{a}}$., Professora do Departamento de Ciências Básicas e Sociais, Universidade Federal da Paraíba, CEP 58220-000, Bananeiras (PB), Brasil. venia camelo@hotmail.com

3 Licenciado em Ciências Agrárias, Doutorando em Ciências Florestais, Universidade Federal Rural de 40 Pernambuco, Rua Manuel de Medeiros, s/n, Dois Irmãos, CEP 52171-900, Recife (PE), Brasil. nailson.gba@ hotmail.com

4 Engenheira Agrônoma, Dra ${ }^{\text {a }}$, Professora do Departamento de Agricultura, Universidade Federal da Paraíba, CEP 58220-000, Bananeiras (PB), Brasil. azeredogil@yahoo.com.br

5 Bacharelado em Agroecologia, Universidade Federal da Paraíba, Cidade Universitária, CEP 58220-000, Bananeiras (PB), Brasil. fabianadosanjos2012@hotmail.com.br

Recebido para publicação em 21/03/2014 e aceito em 19/10/2015 
selecionadas no fragmento florestal do CCHSA submetidas a estresse térmico e monitorar as fenofases reprodutivas das espécies estudadas. $O$ experimento foi instalado no Laboratório de Sementes do CCHSA/UFPB e conduzido em germinadores tipo B.O.D. com fotoperíodo de 8 horas em delineamento inteiramente casualizado nas temperaturas $\left(20,25,30\right.$ e $40^{\circ} \mathrm{C}$ constantes $)$. As sementes foram distribuídas sobre papel-toalha umedecido com água destilada equivalente a três vezes o peso do papel seco. Foram utilizadas quatro repetições de 25 sementes por tratamento. Os dados de germinação e Índice de Velocidade de Germinação (IVG) foram submetidos à análise de variância e regressão polinomial. A germinação de sementes de Pterogyne nitens Tul. foi afetada pelas temperaturas a que foram submetidas, a faixa de temperatura com maiores porcentuais de germinação foi entre 25 e $40^{\circ} \mathrm{C}$. A temperatura elevada $\left(40^{\circ} \mathrm{C}\right)$ aumentou acentuadamente a germinação e o vigor das sementes de Senegalia tenuifolia L. Britton e Rose. $\mathrm{O}$ maior IVG da espécie Enterolobium contortisiliquum (Vell.) foi obtido na temperatura de $40^{\circ} \mathrm{C}$. Os resultados indicam a temperatura ótima e a amplitude térmica para a germinação e desenvolvimento inicial das plântulas dos táxons estudados no seu habitat.

Palavras-chave: semente florestal nativa; Mata Atlântica; fatores abióticos.

\section{INTRODUCTION}

The habitats destruction related to fragmentation can lead to serious consequences for any type of vegetation, mainly for the Atlantic Forest in northeastern Brazil and for the local context, which is extremely fragmented, specifically for the high wet forests and associated ecosystems in the state of Paraíba, Brazil. Thus, species that occur in these fragments are probably having some kind of impact, requiring studies correlating data population structure with seed ecophysiology, essential to indicate those species that need special attention before the implementation of conservation actions. The knowledge of the biodiversity of a region is a basic prerequisite for the management and the management of their genetic diversity, especially in relation to plant species. Thus, it is important to know the preferences of the species for certain sites or biophysical conditions that can determine the abundance of their populations, or even the geographical distribution of these taxa (ANDRADE; FABRICANTE; ALVES, 2008).

The altitude marshes of Paraiba state and associated ecosystems, according to Xavier (2009), have been reducing their forests since the earliest times by agricultural occupation, the removal of wood, or even to vacate space, seeking other more profitable economic activities, generating immediate results to the economy. However, it is possible to observe a sharp decline of these economic activities in municipalities with marsh, combined with the depletion of the currently available natural resources.

According to the Sociedade Nordestina de Ecologia (2002), Paraíba state originally had $12 \%$ of its territory covered by forest formations of this biome, with a dramatically reduction in the area, leaving only $1.2 \%$ of this vegetation. Silva and Tabarelli (2000) affirm that there are only 949 square kilometers of forest in the swamps of Paraíba and Pernambuco, represented by the semideciduous forest and only 25 square kilometers of rain forest in open bogs. Besides this, forests in bogs are extremely fragmented.

The altitude swamps of the northeast areas of the country are areas with different microclimates from the context in which the areas are inserted (semiarid region). This moisture characteristic is associated with orographic effect, highlands and plateaus between 600 and 1,100 m above sea level, which increase the rainfall levels and the lower temperatures, which form "islands" with a different microclimate. Its forest formations are disjunctions of Atlantic Forest, marooned by the 'Caatinga' vegetation, a condition that makes these remaining areas of high biodiversity (BARBOSA et al., 2004). According to Veloso, Rangel-Filho e Lima (1991), this typology can be considered as a vegetation refuge or a relic, since it presents peculiarities in the floristic, physiognomy and ecological terms, different from the context in which it appears.

Since the altitude swamps present climatic conditions very favorable to agriculture, they have been considered priority areas of occupation and development aiming farming activities. These areas have historically suffered from strong anthropism, that manifests itself in different ways. According to Lins (1989), such climatic conditions favored the expansion of agriculture and especially the monoculture of sugarcane, which, associated with inadequate management practices, restricted the vegetation to small patches. According to Viana e Pinheiro (1998), forest fragmentation appears as a powerful problem because it can cause changes in the floristic and faunal composition, resulting in isolation of populations and even 
in the species extinctions.

Botanical research in forest remnants of Paraiba, particularly with regard to the redemption of germplasm, are still scarce. These studies are essential to technically and scientifically guide the preservationist actions, conservation and sustainable forest management, to be implemented in the future in the state (BARBOSA et al., 2004). According to the mentioned author, the northeast altitude swamps are more humid when compared to the semi-arid region that surrounds the area because of the orographic effect that provides higher rainfall incidence and lower temperatures.

It is important the knowledge of the germinating behavior and the reproductive phenology of the remaining native species from the open Ombrophylous forest to support conservation actions of these ecosystems. In this sense, the determination of appropriate technologies to enable the use of seeds of native species that can develop in these areas will be important tools for the implementation of afforestation and reforestation programs in the state of Paraíba, Brazil.

In this context, the aim of this study was to monitor the reproductive phases and study the germination behavior of seeds of selected native species from the Fabaceae family submitted to heat stress.

\section{MATERIAL AND METHODS}

\section{Research location}

The research was developed in a remnant of an open Ombrophylous forest that belongs to the Forest Reserve of the Federal University of Paraíba - CCHSA / UFPB, Campus III. It is considered an important ecotonal forest fragment of an altitude swamp located in the microregion of 'Brejo Paraibano', in the city of Bananeiras - PB state, Brazil, being one of its main fragments with approximately 35.5 ha, which coordinates are: $6^{\circ} 46^{\prime} \mathrm{S}$ and $35^{\circ} 38^{\prime} \mathrm{W}$. Gr., with altitude variation between 510 and $617 \mathrm{~m}$ above sea level (Fig.1). The climate of the region is classified as As' (tropical rainy) hot and humid, according to Köppen's classification and is characterized by having a maximum temperature of $38^{\circ} \mathrm{C}$ and minimum temperature of $18^{\circ} \mathrm{C}$, with rains from autumn to winter (concentrated in May and August). The soil of the reserve is a Distrophic Yellow Oxisol, with loamy texture to sand and rainforest evergreen phase. Geomorphologically, it is characterized by the wavy relief (EMBRAPA, 1999).

The remaining studied area has important specimens that represent plant typology with high genetic and ecological importance for the preservation of the local fauna and flora. The fragment is from secondary formation, with some points in the climax phase with approximate age of 30 years. According to older residents of the city, this area was previously used mainly for coffee and banana production (SANTOS, 2013). According to the same author, who studied Floristic in the same forest fragment, the main families found in the area are: Fabaceae, Sapindaceae, Malvaceae, Anacardiaceae, Myrtaceae, Melastomataceae, Bignoniaceae, Lauraceae, Hypericaceae, Urticaceae, Moraceae and Solanaceae.

\section{Species identification, selection and monitoring}

The fruits of the selected Fabaceae family were processed and then the seeds were submitted to germination tests at the Seed Laboratory of the Department of Agriculture (DA) of the CCHSA - Campus III - the Federal University of Paraíba (UFPB), Bananeiras - PB state, Brazil.

On every 15 days, hiking was performed throughout the remaining forest to search for fertile botanical structures, branches with flowers and/or fruits. The vegetative-reproductive material was collected and identified by comparison using specialized literature, expert consultation, and comparing to the herbarium specimens in the Herbarium "Jaime Moraes Rabbit" (EAN) of the Center for Agricultural Sciences (CCA) of the Federal University of Paraíba (UFPB), when species were subsequently incorporated into the same.

After identification, ten plants of Fabaceae family were selected and marked, since it is the most important family for the forest fragment and the following species were selected, being the ones with the most importance value: Anadenanthera colubrina (Vell.) Brenan (VI=17,583), Pterogyne nitens Tul $(\mathrm{VI}=3,178)$, Enterolobium contortisiliquum $(\mathrm{VI}=3,009)$ and Senegalia tenuifolia L. Britton and Rose 


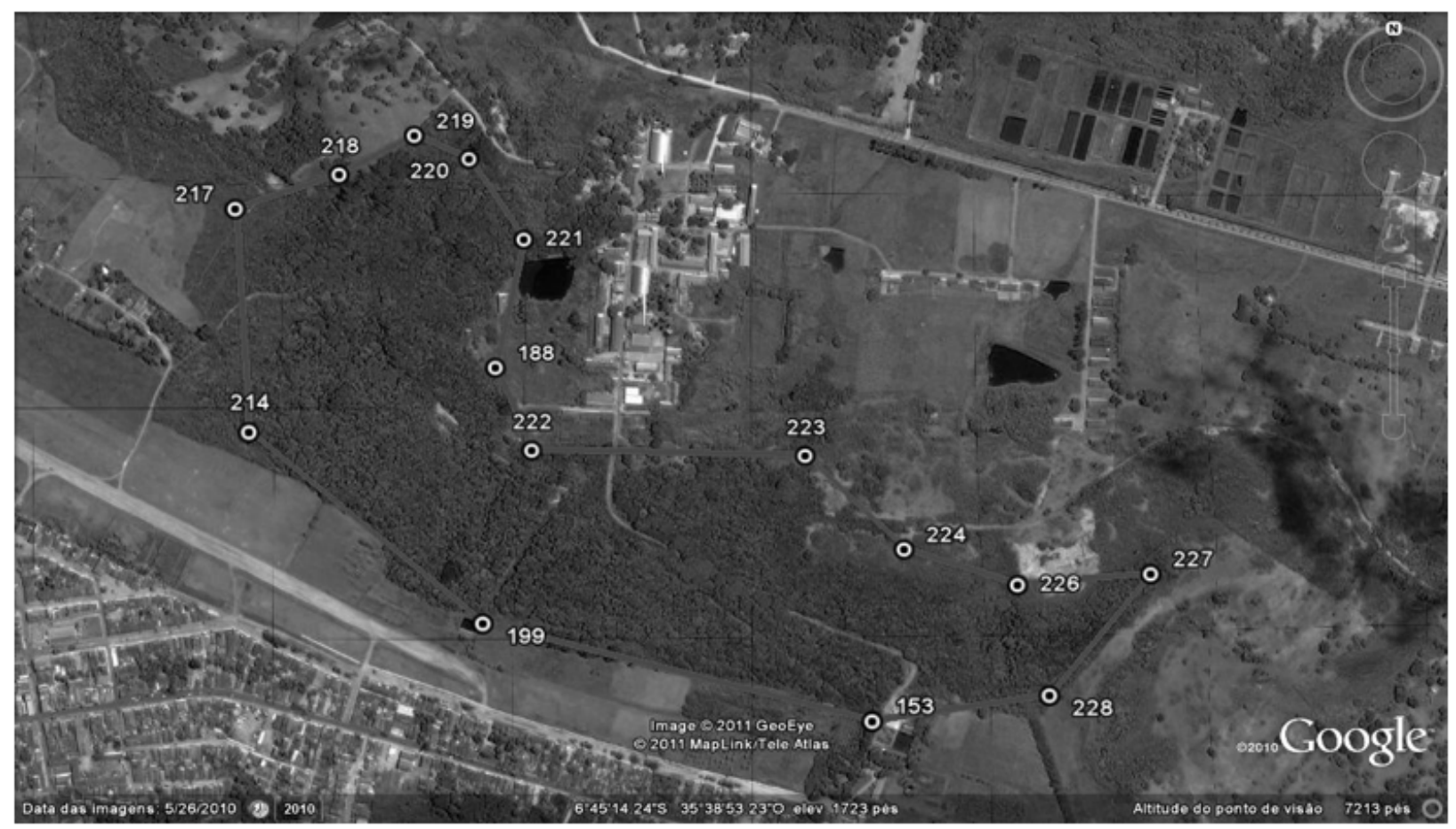

FIGURE 1: Geographic location of the CCHSA / UFPB, remaining reserve with an open ombrophylous forest in the municipality of Bananeiras - PB state, Brazil.

FIGURA 1: Localização geográfica de CCHSA/UFPB, reserva remanescente com Floresta Ombrófila aberta no município de Bananeiras - PB, Brasil.

(VI=0,562), all from the Fabaceae family. Once identified and marked in the field, all matrixes were followed and monitored, through in loco observations, from August 2012 to December 2012, for the collection of the flowering and fruiting data.

The fruits were collected directly from plants with the aid of a trimmer or on the soil, following by manual processing to obtain the seeds.

\section{Seed germination}

The study was conducted at the Seed Technology Laboratory (LATES) of the Department of Agriculture (DAP) - Campus III - at the Federal University of Paraíba (UFPB) Banana - PB state, Brazil.

The fruits and seeds of the studied species were taken from vigorous plants matrices previously selected, marked, mapped and georeferenced. For the choice of the matrix, the observed characteristics were: vigor, branches, flowering, fruiting and productivity. For each species, 10 matrices were selected to a greater germplasm diversity.

Of all monitored species, only seeds from Angico (Anadenanthera colubrina) Calombi (Senegalia tenuifolia), madeira-nova (Pterogyne nitens) and Timbaúva (Enterolobium contortisiliquum) were germinated at different temperatures, since a fruit emission was observed during the evaluation period. The seeds of these four species, therefore, were germinated at temperatures of $20,25,30$, and $40^{\circ} \mathrm{C}$ in BOD type chambers, with eight hours of photoperiod, making four treatments with four replications of 25 seeds, which were distributed over two paper towels, covered with a third and organized in rolls. Prior to the seed distribution on the paper towel, it was moistened with a quantity of distilled and deionized water equivalent to three times the mass of the dry paper. The rolls were wrapped in transparent plastic bags in order to prevent loss of water by evaporation. The following characteristics were evaluated: germination percentage and germination speed index, which data were submitted to analysis of variance and polynomial regression. 


\section{RESULTS AND DISCUSSION}

On Table 1, it is possible to observe the time when the specimens presented the flowering stage followed by the month of sampling, between August, 2012 and December, 2012. From the selected taxon, the first species to show the flowering was 'Angico' during the months of January and February and with collection in August 2012. According to Medeiros et al. (2013), studying the phenology in the same forest fragment, the taxon Anadenanthera. colubrina presented constant fruiting from August to December, 2012, with a decline in January, 2013. 'Calombi' started the flowering in September, with collection in December. The species Pterogyne nitens started the flowering in August, with the beginning of fruiting and collection in October 2012. For E. contortisiliquum, it was observed the beginning of the flowering in August, and fruiting and collection in October, 2012.

'Angico' seeds (Anadenanthera colubrina) did not germinated at the temperatures that they were submitted, possible due to a high fungi incidence in the seeds.

The germination of Pterogyne nitens seeds were affected by the temperatures used. The higher germination observed was about $59 \%$ at $25^{\circ} \mathrm{C}$. For the lower $\left(20^{\circ} \mathrm{C}\right)$ and higher temperatures $\left(30\right.$ and $\left.40^{\circ} \mathrm{C}\right)$, the germination was reduced to $40 \%$ (Figure 2). The vigor data (GSI) of Pterogyne nitens did not fit in the polynomial regression model, with means of $1.10,1.69,1.79$ and 2,14 for the temperatures of $20^{\circ} \mathrm{C}, 25^{\circ} \mathrm{C}$, $30^{\circ} \mathrm{C}$ and $40^{\circ} \mathrm{C}$, respectively.

During the germination process, the influence of the temperature can provide information about the plant establishment and regeneration in natural conditions (CONY; TRIONE, 1996).

For the development of Pterogyne nitens seeds at temperatures of 30 to $40{ }^{\circ} \mathrm{C}$, it presented lower

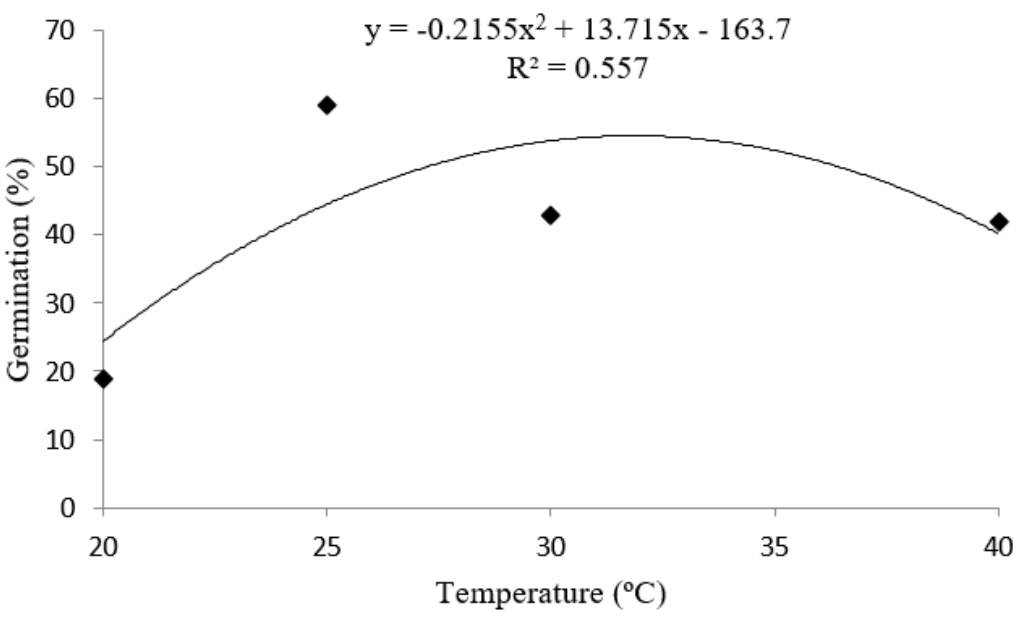

FIGURE 2: Pterogyne nitens germination at different temperatures.

FIGURA 2: Germinação de sementes de Pterogyne nitens em diferentes temperaturas.

TABLE 1: Species selected in the forest fragment: time of flowering phenology and seed collection (IV = Importance Value).

TABELA 1: Espécies selecionadas no fragmento florestal: época da fenofase floração e coleta das sementes (VI = Valor de Importância).

\begin{tabular}{l|cc|c}
\hline Popular name & Scientific name & Flowering (month)) & Collection (month) \\
\hline Angico vermelho & Anadenanthera colubrina & January/February & August \\
Calombí & Senegalia tenuifolia & September & December \\
Madeira nova & Pterogyne nitens & August & October \\
Timbaúva & Enterolobium contortisiliquum & August & October \\
\hline
\end{tabular}


reduction for this species germination. For 'madeira-nova', the range of temperature that promoted higher germination percentage was 25 to $40^{\circ} \mathrm{C}$. The higher temperature range in which the Pterogyne nitens seeds can germinate gives the species adaptative advantage (NASSIF; PEREZ, 2000).

Regarding the Senegalia tenuifolia seeds, it is possible to observe an increase in the germination percentage according to the temperature increase. Under the temperature of $20^{\circ} \mathrm{C}$, the germination observed was very low (4\%), increasing to $43 \%$ with the use of a temperature of $40^{\circ} \mathrm{C}$ (Figure 3), demonstrating that the germination capacity of this taxon depends on high temperatures.

An exponential increase in seed vigor of Senegalia tenuifolia was observed through the evaluation of the germination speed index (GSI), with the highest value (2.3) obtained at $40^{\circ} \mathrm{C}$ and the lowest $(0.1)$ at a temperature of $20^{\circ} \mathrm{C}$. The high temperature markedly altered the Senegalia tenuifolia seed vigor (Figure 4). These results indicated the optimum temperature and the temperature range for germination and early development of the taxon seedlings in their habitat. Data germination and IVG of Senegalia tenuifolia

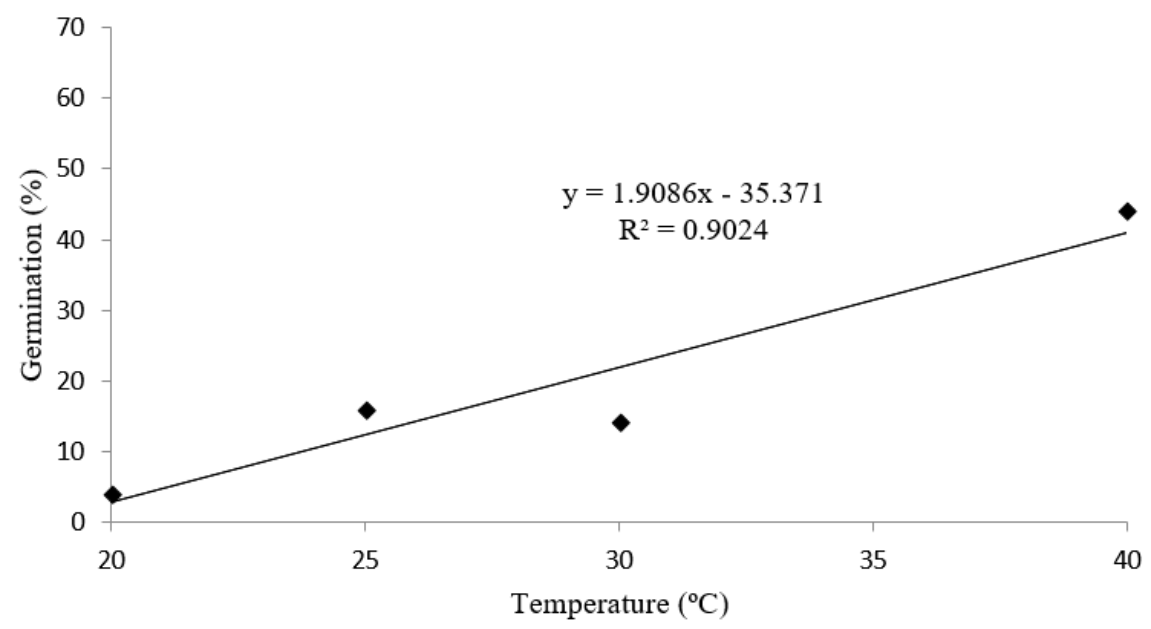

FIGURE 3: Senegalia tenuifolia germination at different temperatures.

FIGURA 3: Germinação de sementes de Senegalia tenuifolia em diferentes temperaturas.

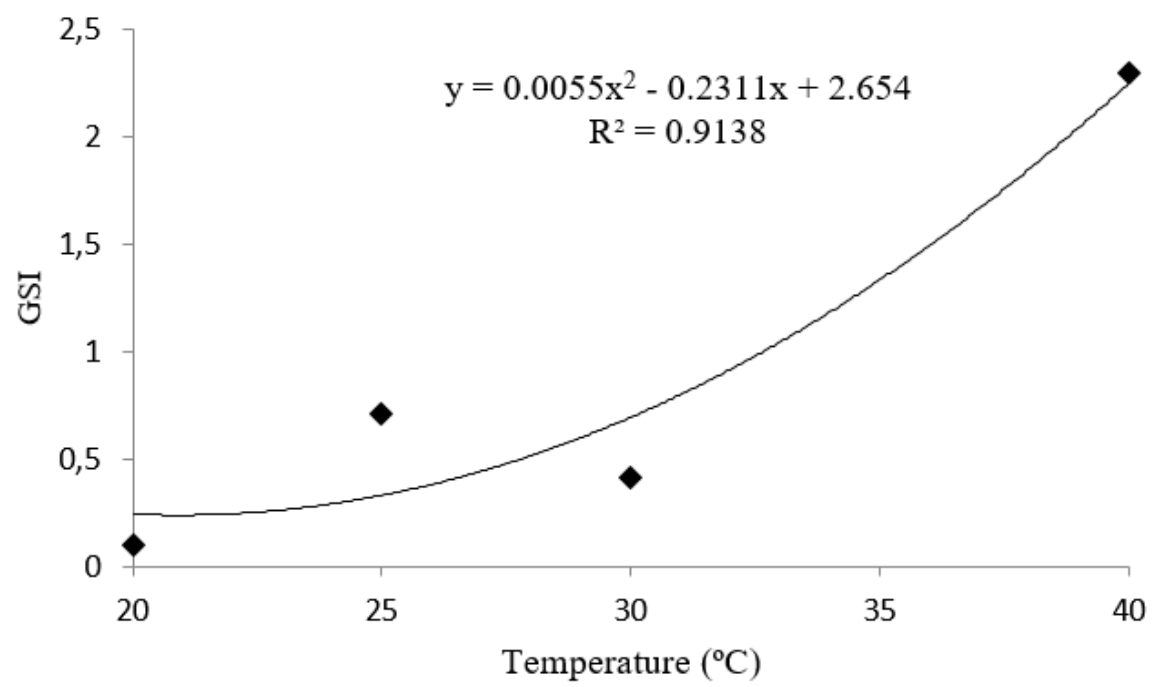

FIGURE 4: Germination speed index of Senegalia tenuifolia at different temperatures.

FIGURA 4: Índice de velocidade de germinação de sementes de Senegalia tenuifolia em diferentes temperaturas. 


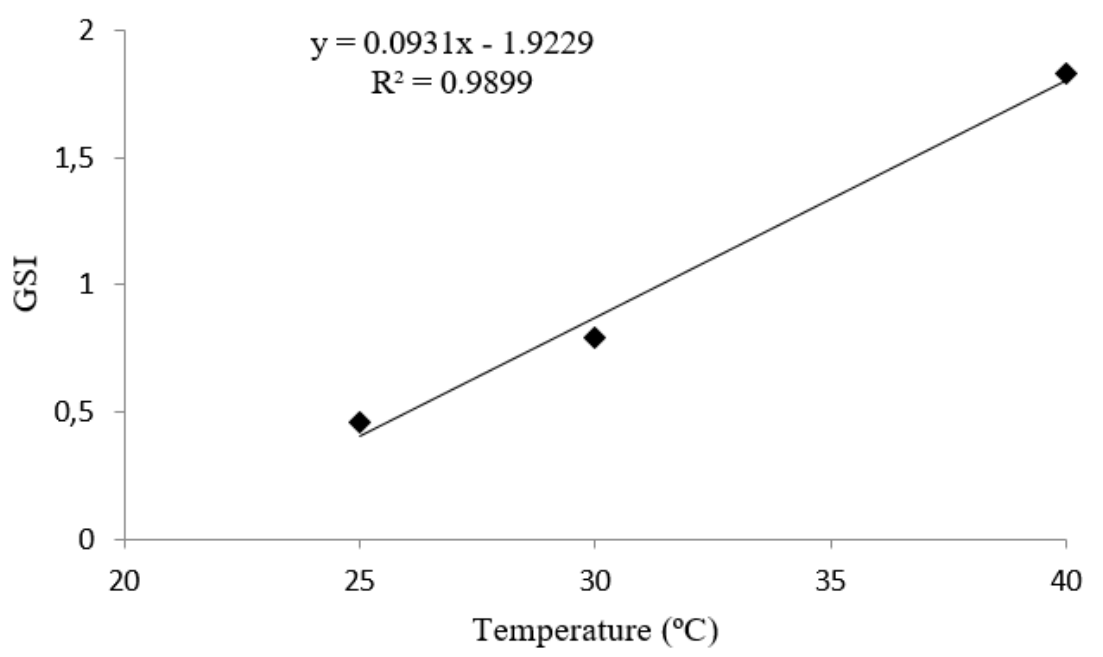

FIGURE 5: Germination Speed Index ofTimbaúva (Enterolobium contortisiliquum) at different temperatures. FIGURA 5: Índice de Velocidade de Germinação de sementes de timbaúva (Enterolobium contortisiliquum) em diferentes temperaturas.

were higher at $40^{\circ} \mathrm{C}$, a fact that may be related to the reproductive strategy of the species. According to the monitoring realized in the studied area, it was found that the time of collection of the fruits and seeds of the studied species occurs in the dry season (December), when the temperatures are high in the region.

The Senegalia tenuifolia is a common species in the swamps of the northeast of the country, in semideciduous forest, dense ombrophylous forest and in 'Restinga', in areas with low altitude, ciliary forests, edges or vegetation in regeneration (BARROS, 2011). It is a species found in the forest fragment - altitude swamp in the municipality of Bananeiras-PB state, Brazil, and is considered to have a climbing habit, being necessary to obtain more information about their ecological importance and reproductive biology. Romaniuc Neto et al. (2012) observed fruit senescence, more evident in the middle of the dry season for woody and herbaceous climbing plants in the riparian forest.

For 'timbaúva' seeds, (Enterolobium contortisiliquum), the germination data did not fit in a linear regression model, however, a linear increase was observed when the vigor (GSI) was evaluated. Along with an increase in the temperatures, higher GSI values were observed, with a maximum (1.83) at $40^{\circ} \mathrm{C}$ (Figure 5). The tegument of this species is very hard and since no treatment was performed to overcome the dormancy, the high temperature has probably acted as a determining factor for a vigor increase. Azeredo et al. (2003), studying forest species of the Atlantic Forest obtained GSI below 0.5 for the seeds of the species Enterolobium contortisiliquum, without pre-germination treatment.

According to the presented results, it is suggested that for a higher vigor of the species Senegalia tenuifolia and Enterolobium contortisiliquum, the temperature of $40^{\circ} \mathrm{C}$ is adequate.

According to Baskin and Baskin (1988), the germination percentage tends to be higher at temperatures corresponding to the period of the year where environmental conditions are favorable to the emergence and plant establishment. For the studied species (Pterogyne nitens and Senegalia tenuifolia), the temperature range with higher percentages of germination was between 25 and $40^{\circ} \mathrm{C}$, and $40^{\circ} \mathrm{C}$, respectively. It is important to observe that the collection of seeds of these species in the studied fragment was carried out from October to December, period of dry season.

Studies that focus on reproductive biology and seed ecophysiology are needed to establish the strategy of conservation for these species. 


\section{CONCLUSIONS}

The temperature of $40^{\circ} \mathrm{C}$ is suitable for Senegalia tenuifolia seed germination and vigor.

For Pterogyne nitens, the range of temperature that resulted in a larger percentage of germination was between 25 and $40^{\circ} \mathrm{C}$.

The highest vigor (germination speed index) of the species Enterolobium contortisiliquum was obtained at a constant and high temperature of $40^{\circ} \mathrm{C}$;

For the studied taxons in the forest fragment, the optimum temperature of germination for the species Pterogyne nitens was $25^{\circ} \mathrm{C}$ and for the Senegalia tenuifolia and Enterolobium contortisiliquum the highest vigor was observed at $40^{\circ} \mathrm{C}$. The temperature range from 25 to $40^{\circ} \mathrm{C}$ is satisfactory for the germination of Pterogyne nitens and for the early development of its seedlings in the habitat.

\section{REFERENCES}

ANDRADE, L. A.; FABRICANTE, J. R.; ALVES, A. S. Algaroba (Prosopis juliflora (Sw.) DC.: impactos sobre a fitodiversidade e estratégias de colonização em área invadida na Paraíba, Brasil. Natureza e Conservação, Curitiba, v. 6, n. 2, p. 61-67, 2008.

AZEREDO, G. A. et al. Germinação em sementes de espécies florestais da mata atlântica (Leguminoseae) sob condições de casa de vegetação. Pesquisa Agropecuária Tropical, Goiânia, v. 33 n. 1, p. 11-16, 2003. BARRoS, M. J. F. Senegalia Raf. (Leguminosae, Mimosoideae) do Domínio Atlântico, Brasil. 2011. 120 f. Dissertação (Mestrado em Botânica) - Instituto de pesquisas Jardim Botânico do Rio de Janeiro, Rio de Janeiro, 2011.

BARBOSA, M. R. V. et al. Diversidade florística na Mata do Pau Ferro, Areia, Paraíba. In: PÔRTO, K. C.; CABRAL, J. J. P.; TABARELLI, M. (Org.). Brejos de altitude em Pernambuco e Paraíba história natural, ecologia e conservação. Brasília: Ministério do Meio Ambiente, 2004. p. 229-254. (Série Biodiversidade, 9).

BASKIN, C. C.; BASKIN, J. M. Germination ecophysiology of herbaceou plant species in a temperate region. American Journal of Botany, Baltimore, v. 75, n. 2, p. 286-305, 1988.

CONY, M. A.; TRIONE, S. A. Germination with respect to temperature of two Argentinean Prosopis Species. Journal of Arid Environments, London, v. 33, p. 225-236, 1996.

EMBRAPA. Centro Nacional de Pesquisa de Solos. Sistema brasileiro de classificação dos solos. Brasília: Embrapa-SPI, 1999. p. 412.

LINS, R. C. As áreas de exceção do agreste de Pernambuco. Recife: SUDENE/PSU/SER, 1989. 402 p. (Estudos Regionais, 20).

MEDEIROS, R. L. S. et al. Fenologia reprodutiva de Anadenanthera colubrina (Vell.) em Brejo de Altitude no município de Bananeiras, Paraíba. In: ENCONTRO DE ECOLOGIA DA PARAÍBA, 2013. Anais... Rio Tinto, 2013. 9 p.

NASSIF, S. M. L.; PEREZ, S. C. J. G. A. Efeitos da temperatura na germinação de sementes de amendoim do campo (Pterogyne nitens Tul.). Revista Brasileira de Sementes, Londrina, v. 22, n.1, p. 1-6, 2000.

ROMANIUC NETO, G. J. V. et al. Caracterização florística, fitossociológica e fenológica de trepadeiras de mata ciliar da Fazenda Campininha, Mogi Guaçu, SP, Brasil. Hoehnea, São Paulo, v. 39, n. 1, p. 145-155, 2012.

SANTOS, J. N. B. Levantamento florístico e fitossociológico em um remanescente de Floresta Ombrófila Aberta, Bananeiras - PB. 2013. 80 f. Monografia (Graduação em Ciências Agrárias) - Universidade Federal da Paraíba, João Pessoa, 2013.

SILVA, J. M. C.; TABARELLI, M. Tree species impoverishment and the future flora of the Atlantic Forest of northeast Brazil. Nature, New York, v. 404 p. 72-74, 2000.

SOCIEDADE NORDESTINA DE ECOLOGIA. Mapeamento da Mata Atlântica, seus ecossistemas associados dos estados da Paraíba e do Rio Grande do Norte. Relatório Técnico. 2002. Disponível em: $<$ http://www.sne.org.br>.

VELOSO, H. P.; RANGEL-FILHO, A. L. R.; LIMA, J. C. A. Classificação da vegetação brasileira, adaptada a um sistema universal. Rio de Janeiro: IBGE, 1991. 91 p. 
VIANA, V. M.; PINHEIRO, L. A. F. V. Conservação da Biodiversidade em fragmentos florestais. ESALQ/ USP. Série Técnica IPEF, Piracicaba v. 32, p. 25-42, 1998.

XAVIER, K. R. F. Análise Florística e Fitossociológica em dois fragmentos de Floresta Serrana no Município de Dona Inês, Paraíba. 2009. 76 f. Dissertação (Mestrado em Agronomia) - Universidade Federal da Paraíba, João Pessoa, 2009. 